\title{
DIGLOSIA
}

Terakreditasi Sinta 3 | Volume 3 | Nomor 2 | Tahun 2020 | Halaman 179-188

P-ISSN 2615-725X | E-ISSN 2615-8655

http://diglosiaunmul.com/index.php/diglosia/article/view/45

\section{PENGEMBANGAN BAHAN AJAR MENULIS FABEL DENGAN MODEL SINEKTIK PADA PESERTA DIDIK KELAS VII SMP MUHAMMADIYAH 1 BALIKPAPAN}

\section{Development of Writing Fable Teaching Material with Synectic Model for Seventh Graders Students of SMP Muhammadiyah 1 Balikpapan}

\author{
Muhammad Reza $^{1, *}$, Yusak Hudiyono ${ }^{2}$, Masrur Yahya ${ }^{3}$ \\ ${ }^{1}$ Magister Pendidikan Bahasa dan Sastra Indonesia, FKIP Universitas Mulawarman \\ ${ }^{2,3}$ Universitas Mulawarman \\ Pos-el Korespondensi: mrezahazmi77@gmail.com
}

\begin{abstract}
Learning method, especially at fabel writing is less less variative; as a result, learning process cannot explore students' writing skill. Therefore, the writer found that it needs to do the synectics learning method development in writing skill learning. This research purpose is to develop the synectics method development in writing learning process. This research uses research and Development (R\&D) method, which is stated by Brog and Gall that it consists of ten steps of source development, which in this research, is VII grade students of SMP Muhammadiyah 1 Balikpapan. Data collection is done by doing the questionnaire, observing, interviewing and documenting. This learning method development is declared very feasible by three validators; material expert validator, media expert validator and learning pratitioner. Based on test result, the synectics model can imrpove the students' score through the test process. The observation result of the learning activity is done by observer I and II and is declared very good. Keywords: development of teaching material, synectics model, writing skill learning, writing fable
\end{abstract}

Abstrak: Metode pembelajaran khususnya pada pembelajaran menulis fabel, masih kurang variatif akibatnya proses pembelajaran yang cenderung kurang mampu mengeksplorasi kemampuan menulis peserta didik. Maka dari itu perlunya melakukan sebuah pengembangan metode pembelajaran sinektik dalam pembelajaran keterampilan menulis. Tujuan penelitian ini ialah untuk mengembangan model sinektik dalam pembelajaran menulis. Penelitian ini menggunakan metode Research and Development (R\&D), yang dikemukakan oleh Brog \& Gall yang terdiri atas sepuluh langkah pengembangan. Sumber data dalam penelitian ini ialah peserta didik kelas VII SMP Muhammadiyah 1 Balikpapan. Pengumpulan data dilakukan dengan cara melakukan pengisian angket, tes, observasi, wawacaran dan dokumentasi. Pengembangan metode pembelajaran ini dinyatakan sangat layak oleh ketiga validator, yakni validator ahli materi validator ahli media dan praktisi pembelajaran. Berdasarkan hasil uji lapangan, model sinektik ini juga dinilai dapat meningkatkan nilai hasil belajar peserta didik melalui proses uji lapangan. Hasil pengamatan kegiatan pembelajaran oleh pengamat I dan II menyatakan sangat baik. Kata Kunci: pengembangan bahan ajar, model sinektik, pembelajaran keterampilan menulis, menulis fabel

\section{A. PENDAHULUAN}

Pembelajaran bahasa Indonesia memiliki tujuan untuk memahami dan menerapkan segala aspek pengetahuan tentang bahasa Indonesia, membelajarkan peserta didik tentang keterampilan berbahasa Indonesia yang benar dan baik sesuai dengan tujuan, fungsi, dan situasinya (Khair, 2018, hal. 89). Keterampilan berbahasa terdiri atas empat keterampilan yaitu berbicara, membaca, menyimak, dan menulis. Keterampilan menulis merupakan keterampilan berbahasa yang paling kompleks dibandingkan dengan keterampilan mendengarkan, membaca, dan berbicara. Menurut pendapat Abbas (2006, hal. 125), keterampilan menulis adalah kemampuan mengungkapkan gagasan, pendapat, dan perasaan kepada pihak lain dengan melalui bahasa tulis. Ketepatan pengungkapan gagasan harus didukung dengan ketepatan 
bahasa yang digunakan, kosakata dan gramatikal dan penggunaan ejaan. Rofi'uddin \& Zuhdi (1998) menambahkan bahwa keterampilan menulis merupakan suatu keterampilan menuangkan pikiran, gagasan, pendapat tentang sesuatu, tanggapan terhadap suatu pernyataan keinginan, atau pengungkapan perasaan dengan menggunakan bahas tulis.

Keterampilan menulis merupakan salah satu jenis keterampilan berbahasa yang harus dikuasai siswa. Sejalan dengan hal itu, keterampilan menulis menjadi salah satu kegiatan yang harus dihadapi siswa dalam proses pembelajaran, terutama untuk mata pelajaran Bahasa dan Sastra Indonesia. Melalui kegiatan menulis, siswa diharapkan dapat menuangkan idenya, baik yang bersifat ilmiah maupun imajinatif. Oleh karena itu, sekolah tempat siswa mengenyam pendidikan diharapkan dapat memberikan pembelajaran tentang menulis dengan baik dan menggunakan teknik yang tepat sehingga potensi dan daya kreativitas siswa dapat tersalurkan dengan baik, tidak hanya potensi yang terpendam.

Pembelajaran yang masih cenderung berpusat pada guru terutama pada keterampilan menulis, khususnya pada menulis fabel, menyebabkan peserta didik kurang aktif dan terlihat kurang semangat. Metode konvensional yang dimaksud misalnya pada pembelajaran kompetensi ini, guru mempertontonkan sebuah video cerita kancil. Kemudian, peserta didik diminta untuk menceritakan kembali video si kancil tersebut. Kegiatan pembelajaran dengan metode seperti ini kurang menuntut peserta didik untuk berpikir lebih keras dalam mengeklorasi potensinya. Untuk itu diperlukan inovasi metode pembelajaran agar tujuan pembelajaran dapat benar-benar tercapai.

Observasi proses pembelajaran dilakukan dengan melakukan pengamatan terhadap sikap belajar para peserta didik saat pembelajaran berlangsung. Informasi yang dapat digambarkan ialah adanya indikasi-indikasi peserta didik yang kurang semangat dan beberapa di antaranya tertidur saat pembelajaran. Selain ada yang tidur, fenomena peserta didik yang bicara dengan temannya atau melakukan hal-hal yang tidak ada kaitannya dengan pembelajaran juga dijumpai. Kemudian, peneliti melakukan observasi terhadap hasil belajar peserta didik menulis (menulis fabel dengan model konvensional) menunjukkan hasil yang masih rendah, yakni 67,8 dari KKM kelas 70 . Hal ini menunjukkan bahwa keterampilan menulis fabel peserta didik SMP Muhammadiyah 1 Balikpapan khususnya kelas VII masih perlu ditingkatkan setidaknya bisa mencapai nilai rerata di atas KKM.

Penelitian dan pengembangan metode ini dilakukan dengan tujuan untuk mengetahui desain produk pengembangan model sinektik dan keefektifannnya dalam pembelajaran keterampilan menulis, khususnya pada penulisan fabel.

Model sinektik adalah model sinektik adalah sebuah pendekatan untuk berpikir kreatif yang didasarkan pada pemahaman bersama, bahwa apa yang tampaknya berbeda dapat dikaitkan bersama. Alat utamanya adalah analogi atau metafora. Sinektik Salah satu ciri model sinektik ini adalah proses. Semakin tinggi proses yang dilakukan siswa, semakin terbuka wawasan siswa, maka semakin memungkinkan untuk memperoleh hasil yang tinggi pula. Proses yang dimaksud adalah proses metaforik, yaitu cara membandingkan sesuatu hal yang lain tanpa menggunakan kata pembanding, artinya pembandingan dilakukan dengan analogi. Analogi merupakan komponen strategi yang penting dalam pembelajaran karena akan membuat lebih mudah untuk mengerti masalah atau ide dengan yang sudah dikenal. Analogi menggambarkan kesamaan antara beberapa masalah atau ide dengan yang sudah dikenal di luar materi pelajaran. 
Joyce, Weil, \& Calhoun (2009) mengidentifikasikan proses metaforik ini ke dalam analogi personal (personal analogy), analogi langsung (direct analogy), dan konflik padat (compressed conflict). Ketoga proses metaforik ini digunakan sebagai langkah yang dilakukan oleh guru dalam mewujudkan pembelajaran dengan menerapkan metode sinektik.

Analogi personal (personal analogy) menuntut siswa empati terhadap ide atau objek yang dibandingkan. Siswa menjadi bagian dari elemen fisik suatu problema. Identifikasinya mungkin terhadap individu, perencanaan, binatang, atau benda-benda mati. Analogi personal sangat menekankan keterlibatan empati. Kerelaan melibatkan diri terhadap obyek sangat dibutuhkan dalam analogi personal, semakin rela melibatkan diri maka semakin besarlah konsep jarak yang diperoleh. Besarnya konsep jarak yang ditimbulkan keterlibatan individu dengan obyek akan lebih memungkinkan perolehan kreasi atau pemahaman baru. Adapun tingkat keterlibatan individu dalam analogi personal yaitu: (1) deskripsi orang pertama terhadap fakta-fakta; (2) mengidentifikasi empatetik dengan suatu yang hidup; dan (3) identifikasi empatetik dengan benda mati. Menurut Dahlan (1990), manfaat mengenal tingkatan analogi personal ini bukan untuk mengenal bentuk-bentuk aktivitas metaforik, tetapi untuk memberikan tuntunan bagaimana menetapkan konsep yang baik. Gordon percaya bahwa dengan analogi akan segera dapat menciptakan jarak yang besar dan lebih memungkinkan siswa memperoleh ide-ide baru.

Analogi langsung (direct analogy) dilakukan dengan membandingkan dua objek atau konsep. Perbandingan tidak harus identik dalam segala hal. Fungsinya cukup sederhana, yaitu untuk mentransposisikan kondisi-kondisi topik atau situasi permasalahan asli yang pada situasi lain untuk menghadirkan pandangan baru tentang gagasan atau masalah (Joyce et al, 2009).

Konflik padat (compressed conflict) adalah memberi tekanan pada pertentangan. Dahlan (1990) berpendapat bahwa memberi tentangan pada pertentangan umumnya berbentuk dua buah kata yang bertentangan misalnya: lesu-agresif, kawan-musuh, dan sebagainya. Pertentangan-pertentangan tersebut memberikan pemahaman yang luas terhadap suatu obyek yang baru. Hal tersebut dapat merefleksi kecakapan siswa untuk menghubungkan dua kerangka berpikir itu terhadap suatu obyek. Besarnya jarak antara dua kerangka berpikir itu dapat meningkatkan fleksibilitas mental.

Pembelajaran bahasa Indonesia pada Kurikulum 2013 adalah pembelajaran berbasis teks. Pembelajaran berbasis teks menuntut siswa menggunakan bahasa tidak hanya dijadikan sebagai sarana komunikasi, tetapi sarana untuk mengembangkan kemampuan berpikir. Mata pelajaran bahasa Indonesia merupakan salah satu mata pelajaran yang dapat membangun nilai karakter pada peserta didik. Teks-teks bermuatan karakter/moral menjadi bagian penting dalam pendidikan karakter, apalagi teksteks sastra yang banyak mengandung unsur karakter/moral. Dari beberapa jenis teks yang diajarkan di kelas VII, teks yang menjadi primadona untuk pembelajaran karakter/moral pada anak adalah teks fabel. Jika dibandingkan dengan karya sastra lain, novel, cerpen, atau puisi, fabel lebih dipilih untuk digunakan dalam pembelajaran bahasa yang disisipi pengajaran nilai-nilai karakter. Hal ini dikarenakan cerita fabel lebih mudah dipahami dan lebih menarik perhatian siswa karena tokoh utama dalam cerita fabel adalah binatang.

Fabel adalah cerita tentang kehidupan binatang yang berperilaku layaknya manusia. Fabel termasuk jenis cerita fiksi, bukan kisah tentang kehidupan nyata. 
Fabel sering disebut juga cerita moral karena pesan yang ada di dalam cerita fabel berkaitan erat dengan moral. Masyarakat Indonesia telah lama mengenal fabel sebagai media pengajaran bagi anak anak. Sugihastuti (dalam Fahmy, Subyantoro, Nuryatin, 2015, hal. 88) berpendapat bahwa fabel disebut juga sebagai teks persuasif. Teks persuasif ini terutama mementingkan penerima, pembaca, atau dalam hal komunikasi lisan adalah pendengar. Ciri persuasif inilah yang sering mengantarkan fabel sebagai teks yang mendidik

Senada dengan Sugihastuti, pendapat dari Sulistyorini (2014, hal. 627) yang menyatakan bahwa teks fabel tentunya dalam teks mengandung nilai-nilai moral maupun etika yang dapat ditauladani. Di dalamnya ada sikap, tutur kata, maupun perilaku tokoh dapat diambil nilai-nilai moral yang dapat diajarkan kepada peserta didik. Menurut Danandjaja (dalam Sulistyorini 2014, hal. 628) mengungkapkan bahwa umumnya cerita fabel bertokoh binatang liar, binantang peliharaan, maupun binatang lainnya seperti semut, kepompong, lebah, maupun kupu-kupu.

\section{B. METODE}

Penelitian yang digunakan oleh peneliti pada penelitian ini ialah penelitian pengembangan (Research and Development). Borg \& Gall mengemukakan bahwa penelitian pengembangan adalah suatu proses yang dipakai untuk mengembangkan dan memvalidasi produk pendidikan. Penelitian pengembangan mengikuti langkah-langkah secara siklus. Penelitian pengembangan itu sendiri dilakukan berdasarkan suatu model pengembangan berbasis industri, yang temuan-temuannya didesain untuk merancang produk dan prosedur yang kemudian secara sistematis dilakukan uji lapangan, dievaluasi dan disempurnakan untuk memenuhi kriteria keefektifan, kualitas dan standar tertentu Borg \& Gall (dalam Sugiyono, 2017).

Lebih jauh Sugiyono (2017) mengemukakan bahwa Research and Development adalah metode penelitian yang digunakan untuk menghasilkan produk tertentu, dan menguji keefektifan metode tersebut. Dalam bidang pendidikan Borg \& Gall menyatakan bahwa penelitian pengembangan merupakan metode penelitian yang digunakan untuk mengembangkan, memvalidasi produk yang digunakan dalam pendidikan dan pembelajaran.

Penelitian pengembangan ini memiliki tujuan untuk melakukan perubahan-perubahan dan melihat perubahan-perubahan yang terjadi dalam kurun waktu tertentu. Sugiyono (2017) dalam hal ini juga mengemukakan bahwa penelitian pengembangan ini memiliki tujuan untuk mengembangkan, menemukan, dan memvalidasi suatu produk. Menemukan adalah melakukan penelitian awal yang bertujuan untuk mendapatkan pengetahuan baru tentang konsep dasar. Mengembangkan yaitu bertujuan mengembangkan pengetahuan yang sudah dimiliki atau diperoleh sejak awal. Memvalidasi berarti upaya menguji keefektifan produk-produk yang merupakan hasil pengembangan.

Sumber data pengembangan ini adalah peserta didik kelas VII SMP Muhammadiyah 1 Balikpapan. Pelaksanaan pengembangan metode pembelajaran direncanakan untuk dapat dilaksanakan penelitian pengembangan, yaitu pada semester ganjil tahun pelajaran 2019/2020. Pemilihan SMP Muhammadiyah 1 Balikpapan sebagai subjek penelitian atas beberapa pertimbangan: kondisi peserta didik yang beragam baik secara kemampuan akademik, jenis kelamin dan latar belakang keluarga serta daerah asal peserta didik. kedua kemudahan akses perizinan kepada pihak sekolah, ketiga kemudahan akses terhadap peserta didik yakni kapan saja. 


$\begin{array}{llr}\quad \text { Penelitian } & \text { pengembangan ini } \\ \text { menerapkan } & \text { sepuluh langkah } \\ \text { pengembangan } & \text { sebagaimana yang }\end{array}$
dikemukakan Sugiyono (2017). Langkahlangkah tersebut ialah (1) penelitian dan pengumpulan informasi (Reserch and Information collecting); (2) Perencanaan (Planning); (3) Develop Prelimenary Form and Product, (4) Uji lapangan awal (Prelimenay Field Testing); (5) Uji lapangan awal (Main Product Revision); (6) Uji coba lapangan utama (Main Field Testing); (7) Uji coba lapangan utama (Development Revision Product); (8) Uji lapangan operasional (Operational Field Testing); (9) Revisi Produk Akhir (Final Product Revision); dan (10) Diseminasi dan implementasi produk (Dissemination and implementation).

Pengumpulan data merupakan inti dari setiap kegiatan penelitian. Sebagaimana yang dikemukakan Sugiyono (2017) bahwa "the data reseacrhers collected depend on the nature of their research question and bypotheses". Data yang dikumpulkan peneliti tergantung pada rumusan masalah dan hipotesis. Dalam pengumpulan data kualitatif dilakukan secara alamiah. Bila ditinjau dari teknik pengumpulan data maka teknik dapat dilakukan dengan observasi, wawancara, kuesioner, dan dokumentasi.

Teknik analisis data bertujuan untuk mengolah data yang dihimpun dari hasil wawancara maupun observasi (Sari, 2017; Mulyo, Ilyas, \& Ridhani, 2019). Teknik dalam melakukan analisis data pada penelitian pengembangan ini yakni menggunakan teknik analisis level 4. Analisis data level 4 ialah analisis data untuk meneliti dan menggunakan yang bertujuan mendapatkan produk baru Sugiyono (2017). Teknik analisis pada penelitian pengembangan menggunakan dua jenis anilisis, yaitu analisis kuantitatif dan analisis kualitatif.

\section{PEMBAHASAN}

1. Pengembangan Desain Produk

Secara operasional, kegiatan yang dilakukan pada tahap desain produk menulis fabel dengan model sinektik meliputi: (a) melakukan kajian kurikulum dan mengkaji teori-teori yang mendukung; (b) menentukan kompetensi dasar yang ingin diajarkan; (c) merumuskan indikator pencapaian kompetensi atau tujuan pembelajaran yang ingin dicapai; (d) menyusun RPP; (e) mengumpulkan bahan/materi ajar; (f) menentukan metode pembelajaran yang akan digunakan; (g) menyusun langkah-langkah pembelajaran; (h) merumuskan jenis dan teknik penilaian hasil pembelajaran atau evaluasi.

Hasil penelitian pengembangan ini berupa buku ajar menulis fabel dengan model sinektik dalam pembelajaran keterampilan menulis fabel. Kegiatan pelaksanaan pembelajaran dan kegiatan akhir pembelajaran. berikut ini langkahlangkah pembelajaran menulis fabel dengan model sinektik.

\section{a. Persiapan Pembelajaran}

Tahap persiapan pembelajaran dalam pembelajaran menulis fabel model sinektik terdiri atas beberapa kegiatan. Pertama, menentukan kompetensi dasar yang akan diajarkan. Kompetensi Dasar (KD) yang akan diajarkan atau dicapai dalam pembelajaran harus ditetapkan sejak awal agar dapat disesuaikan dengan metode pembelajaran yang akan digunakan. Setelah menentukan KD, dilanjutkan dengan menetapkan tujuan pembelajaran dengan jelas. Tujuan pembelajaran menulis fabel dengan model sinektik ialah untuk meningkatnya keterampilan menulis siswa sesuai kebutuhan dan perubahan sikap belajar menjadi lebih baik. Selanjutnya RPP disusun setelah guru menetapkan KD dan tujuan pembelajaran untuk menjadi panduan pelaksanaan pembelajaran. Pemilihan materi/bahan ajar yang akan diajarkan dilakukan saat persiapan pembelajaran. Materi atau 
bahan ajar yang akan digunakan ialah teks. Terakhir adalah menyiapkan media pembelajaran. media pembelajaran yang pilih harus disesuaikan dengan kompetensi dasar yang akan diajarkan.

\section{b. Tahap Pelaksanaan}

Tahap pelaksanaan ada beberapa kegiatan yang dilakukan oleh guru dan peserta didik agar tujuan pembelajaran yang telah ditetapkan tercapai, guru melakukan beberapa hal antara lain.

(1) Guru menyampaikan tujuan pembelajaran dan memberikan penjelasan tentang manfaat menguasai meteri pembelajaran.

(2) Guru menyampaikan kompetensi pembelajaran yang akan dicapai siswa, yaitu KD tentang materi fabel.

(3) Guru menyampaikan pokok cakupan materi pembelajaran.

(4) Siswa dibagi jadi beberapakelompok yang terdiri 3 sampai 4 orang.

(5) Setelah menyimak penjelasan guru tentang langkah-langkah menulis fabel menggunakan model sinektik. Siswa dipersiapkan untuk memilih gambar karakter hewan yang akan dijadikan cerita fabel.

(6) Sebelum memilih karakter yang akan dijadikan fabel siswa diperkenankan untuk bertanya jawab mengenai materi menulis fabel yang menggunakan model sinektik.

(7) Siswa bersiap mengamati gambar hewan dan bersiap memilih dari pilihan tersebut.

(8) Masing- masing skelompok bertukar pikiran tema apa yang akan di bahas.

(9) Siswa dan guru melakukan sesi tanya jawab berkaitan dengan tema yang dipilih.

(10) Siswa masih secara berkelompok menentukan karakter hewan yang akan di jadikan cerita.

(11) Guru mengarahkan untuk menentukan tema awal yang akan dipilih di dalam cerita tersebut.

(12) Guru meminta siswa membayangkan apabila siswa menjadi tokoh utama yang dibuat tersebut Bayangkanlah dirimu sebagai tokoh utama di dalam cerita fabel tersebut.

(13) Buatlah beberapa konflik dalam fabel buatan tersebut, kemudian bandingkanlah.

(14) Guru meminta siswa membandingkan beberapa konflik tersebut, kemudian dipilih salah satu konflik untuk dijadikan cerita.

(15) Guru meminta siswa menuliskan cerita fabel sesuai dengan langkah langkah tersebut.

(16) Guru meminta Salah satu dari kelompok maju untuk membacakan cerita fabel yang dibuat.

(17) Salah satu dari kelompok maju untuk membacakan cerita fabel yang dibuat.

(18) Siswa saling memberikan umpan balik hasil evaluasi pembelajaran yang telah dicapai.

\section{Penilaian Validator}

Penilaian desain produk dilakukan untuk mengetahui tingkat validitas produk yang dikembangkan berupa buku ajar menulis fabel dengan model sinektik. Metode pembelajaran sinektik dalam pembelajaran keterampilan menulis pada KD Menelaah struktur dan kebahasaan fabel/legenda daerah setempatyang dibaca dan didengar Penilaian desain produk dilakukan oleh tiga orang validator, yakni validator ahli materi dan validator ahli media pembelajaran dan praktisi pendidikan. Validasi ahli materi dilakukan oleh Dra. Sri Rahayu, M.Pd. sebagai dosen di Universitas Balikpapan validator ahli media dilakukan oleh Ryan Angga Pratama, M.Pd. selaku dosen di Universitas Balikpapan dan praktisi Pendidikan dilakukan oleh Sarno, M.Pd. sebagai guru mata pelajaran Bahasa Indonesia.

Penilaian desain produk oleh validator dilakukan masing-masing sebanyak dua tahap. Penilaian tahap I dilakukan oleh validator dengan 
memberikan beberapa masukan untuk dilakukan penyempurnaan. Setelah penelitian melakukan penyempurnaan maka dilakukan penilaian tahap II, baik oleh validator ahli materi, ahli media dan praktisi Pendidikan. Data hasil pengisian angket oleh validasi ahli metode pembelajaran menunjukkan bahwa persentase produk berupa buku ajar menulis fabel model sinektik pembelajaran memperoleh nilai akhir validitas ialah 84,87. Mengacu pada nilai uji validitas tersebut, produk dapat dikatakan layak untuk digunakan dalam pembelajaran.

\section{Hasil Uji Coba Produk}

Hasil Uji coba produk merupakan kegiatan untuk mengetahui apakah produk pengembangan berupa buku ajar menulis fabel model sinektik efektif digunakan dalam pembelajaran keterampilan menulis fabel. Selain untuk melihat efektivitas pembelajaran pada uji coba produk juga bertujuan untuk menguji apakah metode ini dapat meningkatkan keterampilan menulis peserta didik. Uji coba produk dilakukan dengan dua tahap. Pertama uji coba kelompok kecil dan kedua uji coba kelompok besar. Dalam setiap uji coba dilakukan dengan dua kali tes keterampilan berbicara yakni pretes untuk mengetahui kondisi awal peserta didik sebelum mengikuti pembelajaran dengan menulis fabel dengan model sinektik dan postes dilakukan untuk mengetahui kemampuan berbicara peserta didik setelah mengikuti pembelajaran dengan menulis fabel dengan model sinektik.

Pelaksanaan pretes dilakukan dengan pembelajaran menulis fabel dengan menggunakan metode konvensional atau metode pembelajaran pada umumnya yakni dengan ceramah dan penugasan. Untuk melakukan tes keterampilan menulis fabel pada pembelajaran pretes ini, guru menyampaikan sekilas materi pembelajaran, kemudian peserta didik menonton sebuah video dongeng dan menuliskan kembali. Sedangkan postes dilakukan setelah peserta didik mengikuti pembelajaran menulis fabel dengan model sinektik. Postes ini dilakukan dengan kegiatan guru menyampaikan materi kemudian peserta didik diajak untuk berpikir dan menganalogikan seadainya aku menjadi tokoh utama di cerita fabel tersebut, peserta didik di arahkan untuk membuat beberapa konflik lalu dipilih salah satu untuk dijadikan dasar cerita. Penilaian keterampilan menulis fabel tersebut dilhat dari hasil tulisan fabel tersebut ada lima aspek yang dinilai dari hasil tulisan peserta didik tersebut yaitu isi gagasan, sarana cerita, tema, ejaan tanda baca, dan kerapian.

Hasil pretes pada uji kelompok kecil dengan jumlah peserta didik sepuluh orang memperoleh rerata nilai 67,8 . Kemudian setelah mengikuti proses pembelajaran dengan menggunakan model sinektik rerata nilai meningkat menjadi 85,7. Selanjutnya, uji kelompok besar dengan jumlah peserta didik sebanyak 26 orang. Pada pretes uji kelompok besar mendapat rerata nilai 68,8 dan setelah mengikuti proses pembelajaran menulis fabel dengan model sinektik postes menunjukkan adanya peningkatan yakni menjadi 81,70.

\section{Observasi Pembelajaran}

Hasil observasi pembelajaran, pengamat yang dilakukan oleh guru mata pelajaran bahasa Indonesia yaitu Ibu Novianti, S.Pd. memberikan penilaian dengan cara mengisi rubrik isian Alat Penilaian Kinerja Guru (APKG) merupakan penilaian perencanaan pembelajaran yang secara fisik dapat mengamati dokumen RPP. Berdasarkan hasil isian APKG memberikan nilai dengan rerata 89,5. Selain melaui isian APKG yang dilakukan pengamat, uji efektivitas juga dengan pengisian angket respon peserta didik dilakukakan secara langsung yang mengikuti uji produk kelompok besar dan setelah mengikuti proses pembelajaran fabel dengan model 
sinektik. Berdasarkan isian angket respon peserta didik diperoleh nilai 89,3 dan dapat dikategorikan sangat baik (SB).

Selanjutnya, peneliti juga melakukan pengumpulan data dengan wawancara. Wawancara dilakukan kepada guru sebagai pengguna, validator praktisi, dan peserta didik sebagai pihak yang merasakan dampak secara langsung dari penerapan metode pembelajaran ini. Hasil wawancara dari ketiga pihak informan tersebut menyatakan bahwa model pembelajaran sinektik ini sangat baik untuk digunakan dalam pembelajaran keterampilan menulis.

\section{PENUTUP}

Metode sinektik merupakan metode pembelajaran yang digunakan untuk meningkatkan kreatifitas individu dan kelompok. Mendiskusikan pengalaman sinektik dapat membangun perasaan kebersamaan antarsiswa. Siswa belajar tentang kawan sekelasnya saat mereka merespon gagasan atau masalah. Setelah melalui sepuluh langkah pengembangan sebagaimana yang dikemukakan oleh Borg \& Gall dalam penelitian dan pengembangan bbahan ajar menulis fabel dengan model sinektik ini dinyatakan dapat digunakan dalam proses pembelajaran keterampilan menulis. Selain itu model sinektik terbukti efektif untuk meningkatkan keterampilan menulis peserta didik, meningkatkan motvasi belajar peserta didik dan mendapat respons positif dari guru sebagai pengguna dan peserta didik sebagai penerima pembelajaran. Adapun manfaat dari metode pembelajaran sinektik adalah (1) dapat mengembangkan kejelasan pengertian dan internalisasi pada diri siswa tentang materi baru; (2) dapat mengembangkan berpikir kreatif, baik pada diri siswa maupun guru; (3) dilaksanakan dalam suasana kebebasan intelektual dan kesamaan martabat antara siswa; dan (4) membantu siswa menemukan cara berpikir baru dalam memecahkan suatu masalah.

\section{DAFTAR PUSTAKA}

Abbas, S. (2006). Pembelajaran Bahasa Indonesia yang Efektif di Sekolah Dasar. Jakarta: Departemen Pendidikan Nasional.

Adeninawaty, D., Soe'oed, R., \& Ridhani, A. (2018). Penerapan Model Pembelajaran Discovery Learning Strategi Think Talk Write Dalam Meningkatkan Motivasi Dan Hasil Belajar Menulis Teks Ulasan Kelas VIII SMP. Diglosia: Jurnal Kajian Bahasa, Sastra, dan Pengajarannya, 1(2), 75-88.

https://doi.org/10.30872/diglosia.v $1 \mathrm{i} 2.11$

Aminuddin. (2010). Pengantar Apresiasi Karya Sastra. Bandung: Sinar Baru Algensindo.

Arifin, Z. (2012). Penelitian Pendidikan (Metode dan Paradigma Baru) Bandung:Remaja Rosdakarya.

Asih. (2016). Strategi Pembelajaran Bahasa Indonesia. Bandung: Pustaka Setia.

Dahlan, M. D. (1990). Model-Model Mengajar: Beberapa Alternatif Interaksi Belajar Mengajar. Bandung: Dipenogoro.

Devi, P. C. (2018). Pengembangan Bahan Ajar Menulis Teks Prosedur Kompleks Dengan Model Pembelajaran Discovery Learning Menggunakan Media Audio Visual (Video) Di Kelas XI SMA Negeri 1 Samarinda. Diglosia: Jurnal Kajian Babasa, Sastra, dan Pengajarannya, 1(2), 101-114.

https://doi.org/10.30872/diglosia.v $1 \mathrm{i} 2.13$

Djamarah, S. B. \& Zain, A. (2006). Strategi Belajar Mengajar. Jakarta: Rineka Cipta. Fahmy, Z., Subyantoro, S., \& Nuryatin, A. (2015). Pengembangan Buku Pengayaan Memproduksi Teks Fabel Bermuatan Nilai Budaya Untuk Siswa SMP. Seloka: Jurnal Pendidikan Bahasa 
Dan Sastra Indonesia, 4(2), 86-93. Diambil dari https://journal.unnes.ac.id/sju/inde x.php/seloka/article/view/9865

Himang, V. H. (2019). Pengembangan Bahan Ajar Menulis Cerpen Berbasis Pengalaman Siswa Kelas XI SMK . Diglosia: Jurnal Kajian Bahasa, Sastra, dan Pengajarannya, 2(2), 93-102. https://doi.org/10.30872/diglosia.v $2 \mathrm{i} 2.21$

Ismawati, E. 2011. Perencanaan Pengajaran Bahasa. Surakarta: Yuma Pustaka.

Joyce, B., Weil, M., \& Calhoun, E. (2009). Models of Teaching: Model-Model Pembelajaran. Yogyakarta: Pustaka Pelajar.

Khair, U. (2018). "Pembelajaran Bahasa Indonesia dan Sastra (BASASTRA) di SD dan MI". Ar-Riayah: Jurnal Pendidikan Dasar, 2(1), 81-98. http://dx.doi.org/10.29240/jpd.v2i1 .261

Khulsum, U., Hudiyono, Y., \& Sulistyowati, E. D. (2019). Pengembangan Bahan Ajar Menulis Cerpen dengan Media Storyboard pada Siswa Kelas X SMA. Diglosia: Jurnal Kajian Bahasa, Sastra, dan Pengajarannya, 1(1), 1-12. https://doi.org/10.30872/diglosia.v 1i1.4

Kurniawan, H. (2014). Pembelajaran Menulis Kreatif. Bandung: Remaja Rosdakarya.

Mulyo, S., Ilyas, M., \& Ridhani, A. (2019). Pembelajaran Keterampilan Berbicara Dengan Metode Field Trip Pada Peserta Didik Kelas IX SMP Samarinda. Diglosia: Jurnal Kajian Bahasa, Sastra, dan Pengajarannya, 2(2), 115-126.

https://doi.org/10.30872/diglosia.v $2 \mathrm{i} 2.23$

Muslich, M. (2010). Textbook Writing: Dasar-dasar Pemahaman, Penulisan, dan Pemakaian Buku Teks. Yogyakarta: ArRuzz Media.

Novita, I. (2020). Pengembangan Bahan Ajar Menulis Teks Cerpen
Berdasarkan Teknik Storyboard pada Siswa Kelas XI SMA. Diglosia: Jurnal Kajian Bahasa, Sastra, dan Pengajarannya, 3(1), 46-52. https://doi.org/10.30872/diglosia.v $3 i 1.29$

Prastowo, A. (2011). Panduan Kreatif Membuat Bahan Ajar Inovatif. Yogyakarta: Diva Press.

Rajja. (2020). Pengembangan Bahan Ajar Menulis Teks Cerpen dengan Metode Cerpen-gram untuk Siswa Kelas IX di Kecamatan Muara Wahau. Diglosia: Jurnal Kajian Bahasa, Sastra, dan Pengajarannya, 3(1), 24-32. https://doi.org/10.30872/diglosia.v $3 \mathrm{i} 1.26$

Rofi'uddin, A., \& Zuhdi, D. (1998). Pendidikan Babasa dan Sastra Indonesia di Kelas Tinggi. Jakarta: Departemen Pendidikan dan Kebudayaan.

Rusman. (2014). Model-Model Pembelajaran. Jakarta: Raja Grafindo Persada.

Sari, I. N. (2017). Pengembengan Strategi Pembelajaran Tandur Menggunakan Media E-Learning dalam Mengonversi Teks Cerita Pendek Menjadi Teks Drama Siswa Kelas XI SMAN 10 Samarinda. Tesis. Universitas Mulawarman.

Sari, L. K. (2019). Pengembangan Pembelajaran Menulis Teks Ceramah Dengan Model Problem Based Learning Dipadukan Media Gambar Pada Siswa Kelas XI SMA. Diglosia: Jurnal Kajian Bahasa, Sastra, dan Pengajarannya, 2(1), 59-72. https://doi.org/10.30872/diglosia.v $2 \mathrm{i} 1.18$

Septhin, K. (2018). Hubungan Minat Baca Dengan Kemampuan Menulis Teks Ekposisi Siswa Kelas XI SMK Negeri 9 Samarinda. Diglosia: Jurnal Kajian Bahasa, Sastra, dan Pengajarannya, 1(2), 89-100.

https://doi.org/10.30872/diglosia.v $1 \mathrm{i} 2.12$ 
Sugiyono. (2017). Metode Penelitian Kuantitatif, Kualitatif, dan R\&DD. Bandung: Alfabeta.

Sulistyorini, D. (2014). Kriteria Pemilihan Materi Ajar Teks Moral/Fabel Pelajaran Bahasa Indonesia dalam Kurikulum 2013. Prosiding Seminar Nasional TEQIP (Teachers Quality Improvement Program), 627-633. Diambil dari https://adoc.tips/fabel- pelajaran-bahasa-indonesia-dalamkurikulum-2013.html

Sutriyati. (2019). Pengembangan Bahan Ajar Menulis Esai Dengan Memanfaatkan Kearifan Lokal Melalui Pembelajaran Berbasis Proyek (PBP) Siswa SMA. Diglosia: Jurnal Kajian Bahasa, Sastra, dan Pengajarannya, 2(1), 39-46. https://doi.org/10.30872/diglosia.v $2 \mathrm{i} 1.16$ 